\title{
Powder Microscopic, Physicochemical, HPTLC and Antioxidant Studies on Noccik Kudinir Chooranam - A Polyherbal Siddha Formulation
}

\author{
Sujith Thatipelli, Shakila Ramachandran*, Achintya Kumar Mandal, Kallingil Gopi Divya, Mahesh Francis, Koppala Narayana Sunil Kumar, \\ Ganesan Rethinam \\ Siddha Central Research Institute, (Central Council for Research in Siddha, Ministry of AYUSH, Government of India), Anna Hospital Campus, Arumbakkam, Chennai, \\ Tamil Nadu, INDIA.
}

\begin{abstract}
Objectives: To study pharmacognostical, physico-chemical, high performance thin layer chromatography and anti-oxidant activity potential of a Siddha drug "Noccik Kudinir Chooranam" (NKC). Methods: The raw drugs were collected, authenticated and the Kudinir Chooranam was prepared. Then the drug was subjected to powder microscopic diagnosis, physicochemical parameters, Thin Layer Chromatographic photo documentation (TLC), High Performance Thin Layer Chromatographic (HPTLC) finger print profile of successive hexane, successive chloroform, successive ethanol, hydro alcohol (1:1) extract, ethyl acetate solubles of water extract, alkaloid fraction and direct ethanol along with ingredients. The methanol and aqueous extracts were evaluated for total phenol and flavonoid, DPPH radical scavenging activity and superoxide scavenging activities. Results: Different extracts of the drug showed distinct TLC and HPTLC finger print patterns which will be unique to this drug. The antioxidant activity showed significant results which are comparable to standards. Conclusion: The
\end{abstract}

identified powder microscopic characters and the evolved physicochemical parameters would serve as reference tool for quality control and the antioxidant activity would find the much wider therapeutic importance of the drug.

Key words: Noccik Kudinir, Vitex negundo, Allium sativum, TLC, HPTLC, Antioxidant activity

Correspondence

Dr. Shakila Ramachandran,

Siddha Central Research Institute, (Central Council for Research in Siddha, Ministry of AYUSH, Government of India), Anna Hospital Campus, Arumbakkam, Chennai-600106, Tamil Nadu, INDIA.

Phone: +9104426214925

Email: shakilasiva@gmail.com

DOI: 10.5530/jyp.2019.11.76

\section{INTRODUCTION}

Siddha system of medicine has originated from Tamil Nadu, Southern state of India. Siddhars developed this medical system who possessed supernatural powers. Medicinal plants, also called medicinal herbs, have been identified and used in traditional medicine practices since prehistoric times in Siddha system of medicine. Plants synthesis humpty number of chemical compounds for functions including defence against insects, fungi, diseases and herbivorous mammals. It is estimated that in developed countries, herbals constitutes $25 \%$ of total drugs, while in developing countries, it is $80 \%$. Medicinal plants are considered to be safe as there is nil or minimal side effects. In line with the increased demand, the herbal products require pharmacopoeial standards through botanical and chemical characterization, for the quality control. NKC is a poly herbal siddha drug used for the treatment of inflammation, swelling, fever, pain in joint and asthma. ${ }^{1}$ Noccik Kudinir is a liquid form of Siddha medicine which could be prepared freshly and consumed for its therapeutic efficacy. The ingredients of the drugs are all well known; Piper nigrum and Allium sativum are available in all houses as kitchen culinary items and fresh leaves of Piper betle are available in market and only the Vitex negundo needs to be collected. In this communication, authors aimed to formulate NKC in the dried form with the composition of ingredients as per Siddha literature and subject to powder microscopy, physico-chemical parameters for the NKC (powder) and NK (liquid), TLC/HPTLC analysis, total phenol, total flavonoid, super oxide anion radical scavenging activity and DPPH radical scavenging activities.
The human system creates Reactive Oxygen Species (ROS), such as superoxide anion radical, hydroxyl radical and hydrogen peroxide by many enzymatic systems through oxygen consumption. ${ }^{2}$ In small amounts, these ROS can be beneficial as signal transducers. However, during oxidative stress, large amounts of these ROS may favour some human disease conditions such as cancer, hepatic diseases, cardiovascular diseases, ageing and neurodegenerative diseases. ${ }^{3}$

\section{MATERIALS AND METHODS}

\section{Preparation of NKC}

Vitex negundo and Piper betle were collected from the nearby places. Allium sativum and Piper nigrum were procured from the market. All the plants were authenticated with reference to floras. The fresh leaves of Vitex negundo and Piper betle were shade dried, along with Piper nigrum and Allium sativum (fresh), powdered coarsely (NKC) and stored in an air tight container (Table 1).

\section{Powder Microscopy}

The powdered NKC was mounted in glycerine on clean microscopic slides after treating with $10 \% \mathrm{NaOH}$ solution. Slides were observed under Nikon ECLIPSE E200 trinocular microscope and diagnostic characters were identified. Powder characters were magnified to 400X and photographed. The unique characters of individual herbals were identified. ${ }^{4}$ 
Thatipelli, et al.: Pharmacognostic and Antioxidant Studies on Noccik Kudinir Chooranam

Table 1: List of ingredients and composition.

\begin{tabular}{|c|c|c|c|c|c|c|}
\hline S.No & $\begin{array}{l}\text { Tamil name of } \\
\text { the plant }\end{array}$ & Botanical name of the plant & Anatomical part & $\begin{array}{l}\text { Ratio as per } \\
\text { Literature }\end{array}$ & Ration taken & Weight \\
\hline & Nochi & Vitex negundo (Franch.) Rehder & Leaves & 1 handful & 13 handful & $194 \mathrm{~g}$ \\
\hline & Poondu & Allium sativum (Sadler ex Rchb and Mill) & Bulb & $4 \mathrm{~g}$ & $52 \mathrm{~g}$ & $52 \mathrm{~g}$ \\
\hline & Vetrilai & Piper betle $\mathrm{L}$. & Leaves & 10 nos & 130 nos & $209 \mathrm{~g}$ \\
\hline
\end{tabular}

\section{Preparation of Kudinir}

Kudinir (water extract/decoction) was prepared by adding water $(100 \mathrm{ml})$ to NKC $(5 \mathrm{~g})$, boiled till the water content is reduced to $1 / 4^{\text {th }}$ of the water $(25 \mathrm{ml})$ and then filtered.

\section{Chemicals, solvents and materials}

All the solvents used were AR grade (Merck). For visualizing purpose vanillin ( $1 \mathrm{~g}$ ) sulphuric acid in ethanol (5\%) solution (VSA) was used. Standards and reagents were AR grade and all other chemicals were LR (Sigma Aldrich).

\section{Instrument}

For HPTLC, aluminium plate precoated with Silicagel $60 \mathrm{~F}_{254}$ (Merck) was used. Automatic sampler ATS4 for application on TLC plate, twin trough chamber $(10 \times 10 \mathrm{~cm})$ for plate development, visualizer for photo documentation, Scanner 4 with win CATS software for finger prints, TLC plate heater for derivatization (CAMAG, Switzerland), Perkin Elmer's Lambda 25 UV-Visible spectrophotometer for absorbance measurement were used.

\section{Physicochemical parameters}

All the physiochemical parameters for NKC and NK were carried out as per standard methods.

\section{Preparation of extracts}

NKC (1 g) was extracted successively with n-hexane, chloroform and ethanol using Soxhlet apparatus, filtered, concentrated and made up to $1 \mathrm{ml}$. NKC (100 mg) was sonicated with $1 \mathrm{ml} \mathrm{1:1} \mathrm{aqueous} \mathrm{ethanol,} \mathrm{filtered} \mathrm{and}$ used for TLC/HPTLC. The NK was extracted with ethyl acetate repeatedly, combined together, evaporated to $1 \mathrm{ml}$. NKC (5 g) was acidified with $5 \%$ acetic acid solution and kept overnight. Then, filtered, basified with ammonia and brought the solution to basic $\mathrm{pH}$. This solution was shaken with chloroform and chloroform layer was separated, dried and the yield was calculated. This residue was re-dissolved in $1 \mathrm{ml}$ of chloroform for TLC of alkaloids.

\section{Mobile Phases}

The mobile phases for $n$-hexane extract, toluene: ethyl acetate: formic acid (8:0.8:0.5, $v / v / v / v)$; for successive chloroform, toluene: ethyl acetate: diethyl amine $(7: 3.5: 1, v / v / v)$; for successive ethanol, toluene: ethyl acetate: formic acid (5:4:1, $v / v / v)$; for hydro alcohol extract, hexane: toluene: ethyl acetate: formic acid: acetic acid (3:3:4:0.5:0.5, $v / v / v / v / v)$ ); for kudinir, toluene: ethyl acetae: formic acid $(5: 3: 1, v / v / v / v)$; for alkaloid, toluene: ethyl acetate: diethyl amine $(7: 4: 0.5, v / v / v)$, for ethanol extract with ingredients, toluene: ethyl acetate: formic acid $(5: 4: 1, v / v / v)$ were finalised.

\section{TLC/HPTLC}

Extracts $(15 \mu \mathrm{l})$, in 6 different plates $(6 \times 10$ sq.cm) as $8 \mathrm{~mm}$ bands. The plates were developed in the respective mobile phases. The developed plates were air dried, viewed under UV $254 \mathrm{~nm}$ and $366 \mathrm{~nm}$ and the images were documented followed by multi wavelength scanning at these wavelengths using deuterium lamp in absorption/reflection mode. Then the plates were dipped in a dip tank containing VSA reagent and heated at $105^{\circ} \mathrm{C}$ till the appearance of coloured spots. Immediately the derivatized TLC plates were photo documented and scanned at a wavelength of $520 \mathrm{~nm}$ for finger prints.

\section{Antioxidant activity}

The total phenol content was determined by Folin-ciocalteau method. ${ }^{6}$ The standard curve for total phenol using gallic acid and total flavonoid content $^{7}$ using quercetin is $2,4,6,8,10 \mu \mathrm{g} / \mathrm{ml}$ concentration. The sample concentration was 10 and $100 \mu \mathrm{g} / \mathrm{ml}$ respectively. For DPPH free radical ${ }^{8}$ and superoxide anion radical scavenging activities ${ }^{9}$ the extracts in the concentrations $1,10,15,100 \mathrm{mg} / \mathrm{ml}$, standard ascorbic acid in the concentration $25,50,75,100,200,300,400$ and $500 \mu \mathrm{g} / \mathrm{ml}$ were taken.

\section{RESULTS}

The powdered compound formulation of NKC contains the characters pertaining to the bulb of Allium sativum, leaves of Piper betel and Vitex negundo and fruits of Piper nigrum (Figure 1). Elongated thin walled epidermis with a normocytic stomata and spiral vessel elements are the characteristic features of A. sativum; epidermal cells with glandular trichomes, stomata, prismatic crystals and spiral vessels are the distinctive features of $P$. betel leaves; Stone cells of hypodermis, bearer cells, perisperm cells and starch grains are the representative characters of

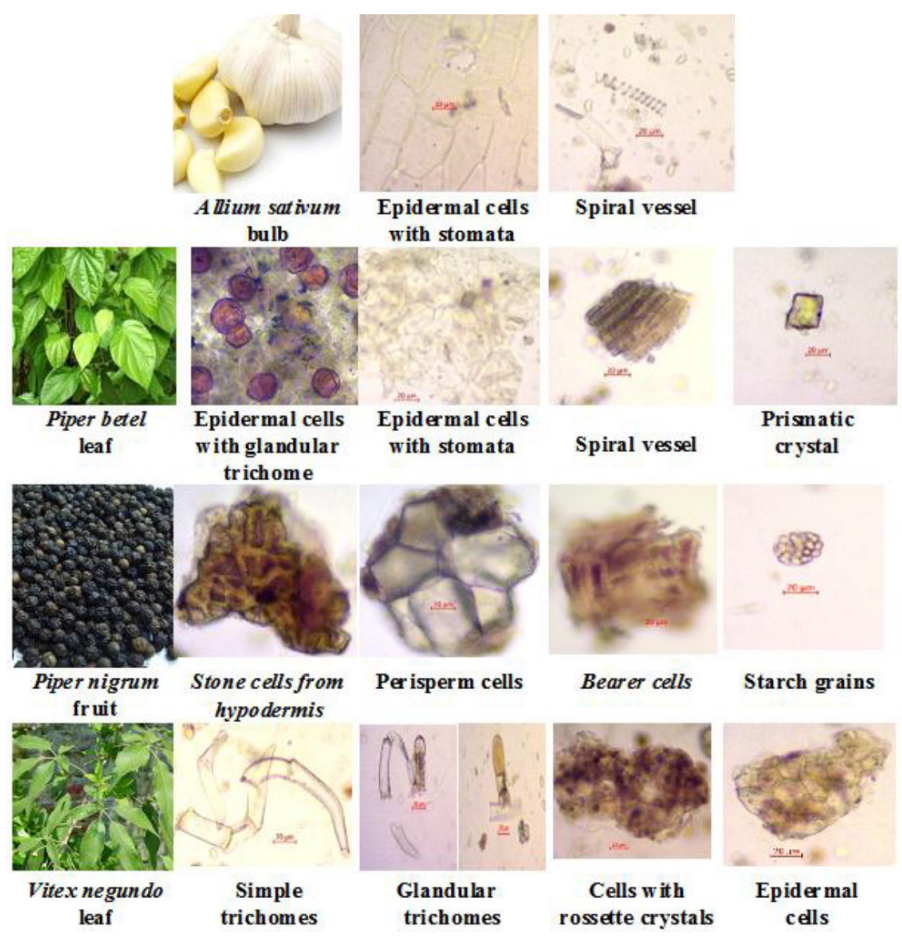

Figure 1: Ingredients and Powder microscopy of NKC. 
P. nigrum fruit and simple unicellular to multicellular trichomes in addition to glandular trichomes, epidermal cells and parenchyma cells containing rosette crystals are specific characters of $V$. negundo leaves.

Physicochemical results of NKC and Kudinir are presented in the Table 2. The TLC of $n$-hexane extract (Figure 2) showed seven spots at $\mathrm{R} f 0.25$, $0.29,0.34,0.38,0.39,0.47,0.52$ (all green) under UV $254 \mathrm{~nm}$; thirteen spots at $\mathrm{R} f 0.15$ (pink), 0.24 (pale blue), 0.30 (pink), 0.33 (pale blue), 0.36 (yellow), 0.41 (pink), 0.42 (yellow), 0.47 (pink), 0.50 (bluish white), 0.55, 0.59 (both pink), 0.61 (blue) and 0.69 (pink) under UV $366 \mathrm{~nm}$; eight spots at $\mathrm{R} f 0.03,0.08,0.18,0.26$ (all purple), 0.34 (yellowish brown), $0.48,0.59,0.97$ (all violet). The TLC of successive chloroform (Figure 2) showed six spots at $\mathrm{R} f 0.14,0.18,0.58,0.74,0.85,0.93$ (all green) under UV $254 \mathrm{~nm}$; fifteen spots at Rf 0.04 (fluorescent blue), 0.06 (pink), 0.07 (brown), 0.09, 0.12 (both pink), 0.16 (brown), 0.18 (green), 0.32 (pink), 0.59 (violet), 0.64 (pink), 0.68 (violet), 0.74 (blue), 0.80, 0.85, 0.94 (all pink) under UV $366 \mathrm{~nm}$; eight spots at $\mathrm{R} f 0.03$ (Bluish Green), 0.08 (blue), 0.18 (pink), 0.26 (light pink), 0.39, 0.51 (both blue) $0.57,0.73$ (both yellow) after dipping in VSR. The TLC of successive ethanol extract (Figure 2) showed 4 spots at $\mathrm{R} f 0.05,0.49,0.59$ and 0.66 (all green) under UV $254 \mathrm{~nm}$; fourteen spots at $\mathrm{R} f 0.03$ (creamy white), 0.05 (pale pink), 0.36, 0.46, 0.51, 0.54, 0.59,0.63 (all pink), 0.67 (sky blue), 0.70, 0.77, 0.84, $0.90,0.99$ (all pink) under UV $366 \mathrm{~nm}$; nine spots at Rf 0.06, 0.35 (both violet), 0.49 (yellow), 0.51, 0.54, 0.58, 0.67, 0.78, 0.98 (all purple) after derivatizing with VSR. HPTLC profile of hexane extract (Figure 2) under UV $254 \mathrm{~nm}$, major peaks (5,7,6 and 8) appeared at Rf0.34(area 34.79\%), $0.48(21.36 \%), 0.40(11.85 \%)$ and $0.52(10.48 \%)$; under $366 \mathrm{~nm}$, major peaks (3,4 and 2) at $\mathrm{R} f 0.35(50.69 \%), 0.41(15.66 \%)$ and $0.24(13.58 \%)$; after derivatization with VSR, at 520nm, showed major peaks $(10,6,8,14$ and 5) at $\mathrm{Rf} 0.57(16.33 \%), 0.35(16.32 \%), 0.47(13.56 \%), 0.95(12.95 \%)$ and $0.27(10.21 \%)$ respectively. HPTLC profile of successive chloroform extract (Figure 2) under UV 254nm, showed major peaks $(9,11,10$ and 7) at Rf0.72(42.59\%), 0.91(20.30\%), 0.83(14.88\%) and 0.57(13.00\%); under $366 \mathrm{~nm}$, showed major peaks (12 and 13) at Rf 0.93(33.69\%), 0.96 (16.98\%); after derivatization with VSR, at $520 \mathrm{~nm}$, showed major peaks (10,11 and 13) at $\mathrm{R} f$ 0.74(32.42\%), 0.90(19.09\%) and 0.95(16.49\%). HPTLC profile of successive ethanol extract (Figure 2) under UV $254 \mathrm{~nm}$, showed major peaks (11, 10 and 8 ) at $\mathrm{R} f$ 0.68(19.93\%), 0.60(14.89\%), 0.49(12.31\%); under $366 \mathrm{~nm}$, showed major peaks (19, 20, 21 and 16) at $\mathrm{R} f$ 0.85(16.21\%), 0.91(15.29\%), 0.96(14.84\%), 0.63(10.41\%); after derivatization with VSR, at $520 \mathrm{~nm}$, showed major peaks $(14,11$ and 9$)$ at Rf 0.98(17.97\%), 0.78(12.05\%), 0.57(10.325\%).

The TLC of hydro alcoholic extract (Figure 3 ) showed six spots at R $f 0.54$, $0.59,0.68,0.73,0.80$ and 0.84 (all green) under UV $254 \mathrm{~nm}$; seven spots at $\mathrm{R} f 0.48$ (Blue), 0.55(Blue), 0.65(Blue), 0.68(Blue), 0.74, 0.66 (both

Table 2: Physicochemical results of NKC and NK.

\begin{tabular}{cccccc}
\hline S.No & Parameters & $\begin{array}{c}\text { Mean } \\
(\mathbf{n}=2)\end{array}$ & S. No & Parameters & $\begin{array}{c}\text { Mean } \\
(\mathbf{n}=2)\end{array}$ \\
\hline LOD at $105^{\circ} \mathrm{C}$ & $19.87^{*}$ & \multicolumn{3}{c}{ Successive Extraction } \\
Total Ash & $6.17^{*}$ & $\begin{array}{l}7 . \\
\text { n-Hexane }\end{array}$ & $4.00^{*}$ \\
& & 8. & Chloroform & $3.50^{*}$ \\
& & 9. & Methanol & $9.00^{*}$ \\
Water Soluble Ash & $2.61^{*}$ & 10. & $\mathrm{pH}(10 \%$ solution $)$ & 6.49 \\
Acid Insoluble Ash & $1.10^{*}$ & 11. & $\mathrm{pH}$ & 6.57 \\
Water Soluble & $41.40^{*}$ & 12. & Total Solids & $2.75^{*}$ \\
Extractives & & & & \\
Alcohol Soluble & $27.60^{*}$ & 13. & Weight per $\mathrm{ml}(\mathrm{g} / \mathrm{ml})$ & 1.03 \\
Extractive & & & & \\
\hline
\end{tabular}

${ }^{\star}$ means w/w \%

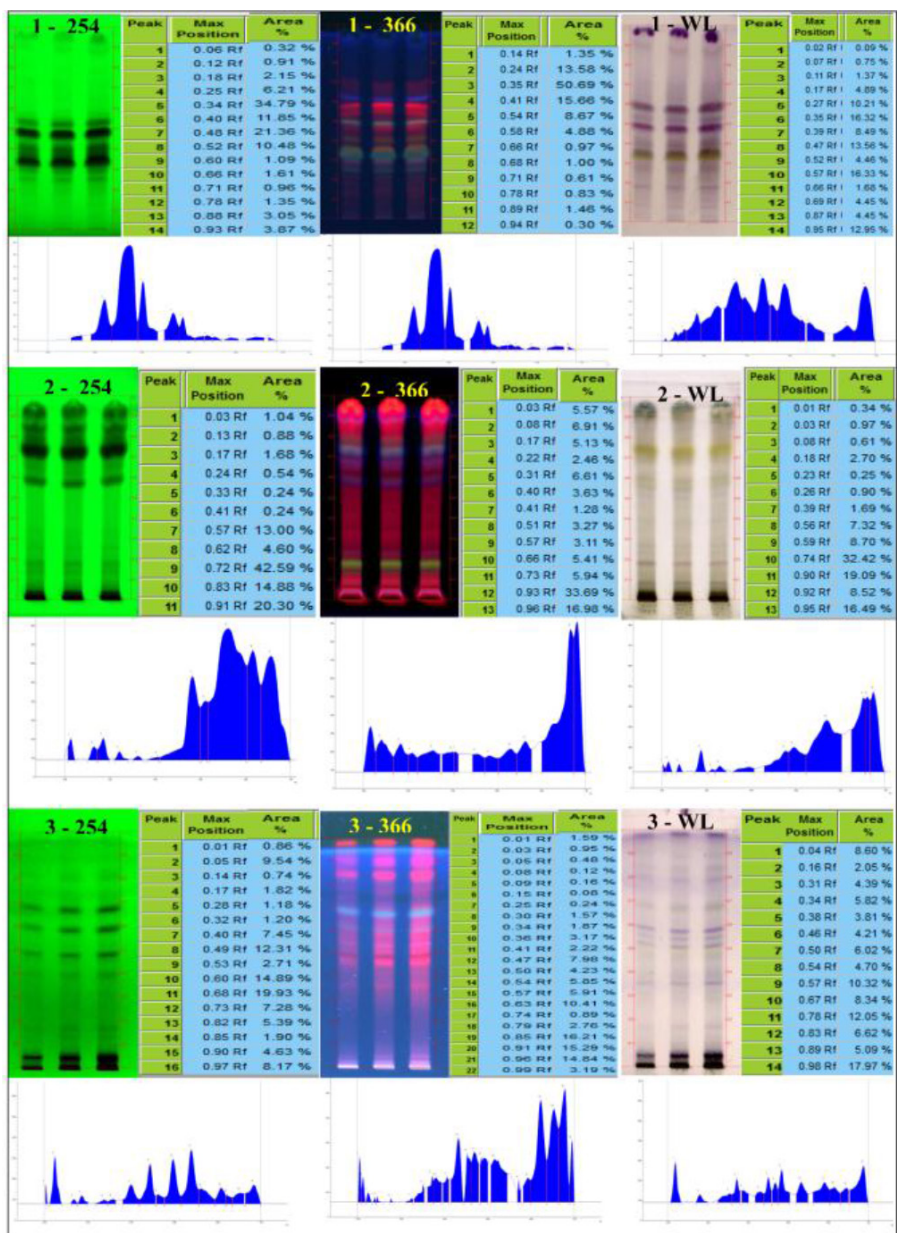

Figure 2: TLC/HPTLC of successive extracts of NKC $1-n$-Hexane; 2 - Chloroform; 3 - Ethanol.

Fluorescent Blue), 0.92(Blue) under $366 \mathrm{~nm}$; five spots at $\mathrm{R} f 0.45,0.53$, $0.60,0.70$ (all grey) and 0.74 (brown) after derivatization with VSR reagent.

The TLC of ethyl acetate solubles of Kudinir (Figure 3), therapeutic dosage form showed ten spots at $\mathrm{R} f 0.04,0.05,0.07,0.09,0.48,0.59,0.66$, $0.80,0.89$ and 0.95 (all green) under UV $254 \mathrm{~nm}$; twelve spots at Rf 0.04 (Blue), 0.38 (Blue), 0.44 (Pale Blue), 0.47 (Pink), 0.53,0.59 (both Pale Blue), 0.64 (Fluorescent Blue), 0.69, 0.72, 0.79 (all Pale Yellow), 0.83 and 0.88 (both Pink) under UV $366 \mathrm{~nm}$; ten spots at $\mathrm{R} f 0.06$ (Violet), 0.38, 0.52, 0.54, 0.56 (all Purple), 0.66 (Yellow), 0.69, 0.78, 0.84 and 0.93 (all Purple).

The TLC of alkaloid fraction of NKC (Figure 3) showed eight spots 0.12, $0.16,0.45,0.64,0.73,0.82,0.92$ and 0.98 (all green) under $254 \mathrm{~nm}$; fourteen spots 0.03 (Fluorescent Blue), 0.14 (Blue), 0.19 (Greenish blue), 0.25, 0.31 (both Pink), 0.44 (Violet), 0.59 (Pink), 0.63 (Blue), 0.66, 0.70 (both Light Green), 0.86 (Pink), 0.90 (Light Green), 0.94 (Fluorescent Green) and 0.97 (Pink) under $366 \mathrm{~nm}$; two spots 0.63 and 0.97 (both orange) after spray with Dragendorff's reagent.

HPTLC finger print of hydroalcohol extract (Figure 3) under UV 254nm, showed major peaks (8 and 7) at $\mathrm{R} f 0.72(47.29 \%)$ and 0.69 (19.60\%); under $366 \mathrm{~nm}$, showed major peak (10 and 9) at $\mathrm{R} f 0.92(46.14 \%)$ and 0.71(19.83\%); after derivatization with VSR, at $520 \mathrm{~nm}$, showed major peaks ( 9 and 8 ) at $\mathrm{R} f 0.74(39.40 \%)$ and $0.70(19.42 \%)$. 


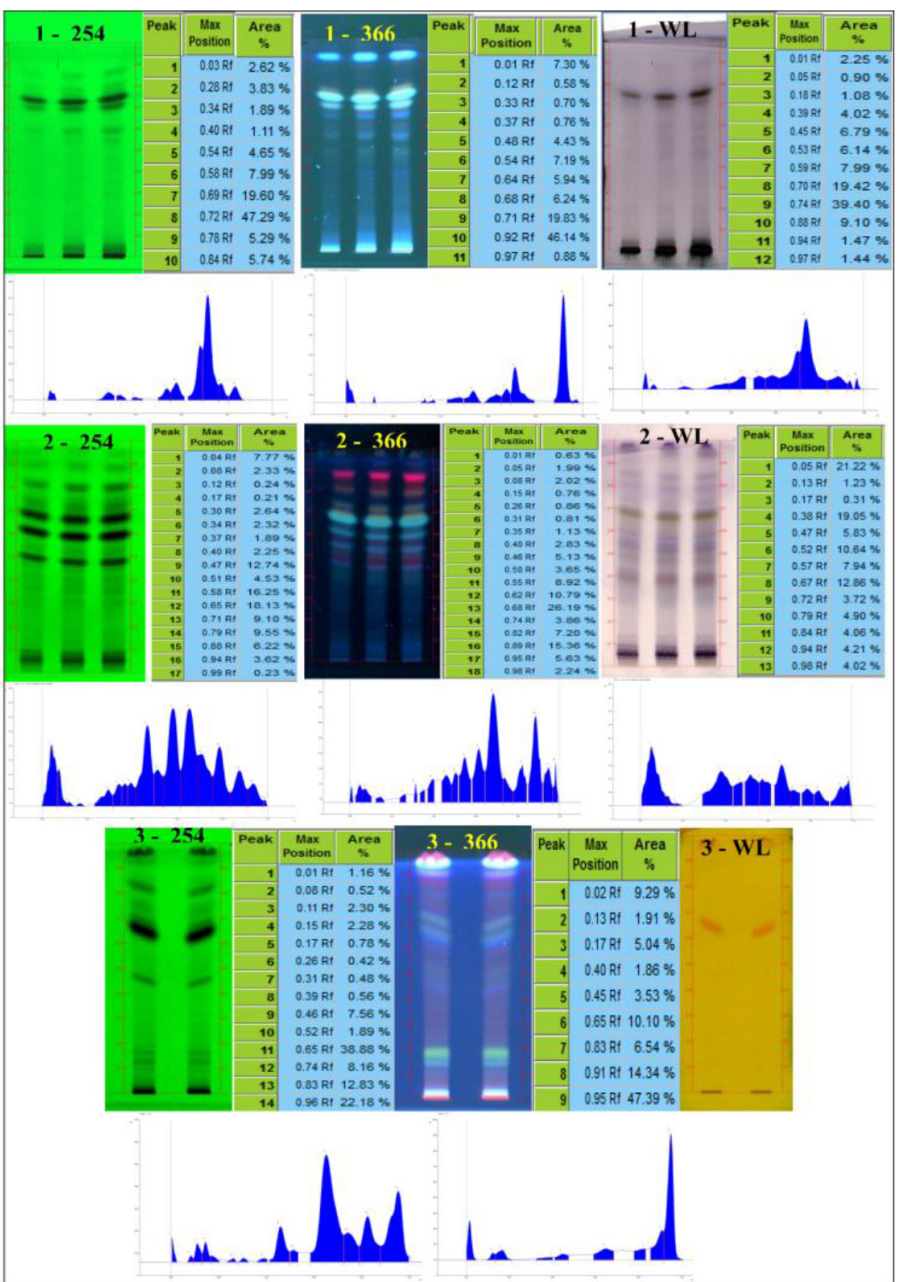

Figure 3: TLC/HPTLC of NKC 1-Hydroalcohol; 2-Ethyl acetate solubles of Kudinir; 3-Alkaloid fraction.

HPTLC finger print profile of ethyl acetate solubles of water extract of NKC (Figure 3), under $254 \mathrm{~nm}$ showed major peaks (12,11 and 9) at $\mathrm{R}$ 0.65(18.13\%), 0.58(16.25\%) and 0.47 (12.74\%); under $366 \mathrm{~nm}$, showed major peaks (13,16 and 12$)$ at $\mathrm{R} f 0.68(26.19 \%), 0.89(15.36 \%)$ and $0.62(10.79 \%)$; after derivatization with VSR, at $520 \mathrm{~nm}$, showed major peaks (1,4,6 and 8$)$ at $\mathrm{R} f 0.05(21.22 \%), 0.38(19.05 \%), 0.52(10.64 \%)$ and $0.67(12.87 \%)$.

HPTLC finger print of alkaloid fraction (Figure 3), at $254 \mathrm{~nm}$ showed major peaks (11,14 and 13) at $\mathrm{R} f$ 0.65(38.88\%), 0.96(22.18\%) and $0.83(12.83 \%)$; under $366 \mathrm{~nm}$, showed major peaks (9,8 and 6) at $\mathrm{R} f$ $0.95(47.39 \%), 0.91(14.34 \%)$ and $0.65(10.10 \%)$. As the TLC plate showed two alkaloid spots at 0.63 and 0.97 , finger print not documented after derivatization with Dragendorff's reagent. The TLC of alcohol extract with ingredients showed that spots of all ingredients in the NKC (Figure 4) and the $3 \mathrm{D}$ chromatogram also represented the ingredients peak in NKC. Total phenol content was estimated as gallic acid equivalents $(\mathrm{mg} / \mathrm{g})$, $25.23 \pm 0.3 \mathrm{mg} / \mathrm{g}$ for NKC aqueous extract and $32.32 \pm 0.406$ for NKC methanol extract, the absorbance was measured at $750 \mathrm{~nm}$. Total flavonoids estimated as quercetin equivalents ( $\mathrm{mg} / \mathrm{g}$ ), $23.04 \pm 0.353 \mathrm{mg} / \mathrm{g}$ for $\mathrm{NKC}$ aqueous extract and $23.26 \pm 0.829$ for NKC methanol extract. The absorbance was measured at $435 \mathrm{~nm}$. The results are represented pictorially in Figure 5.

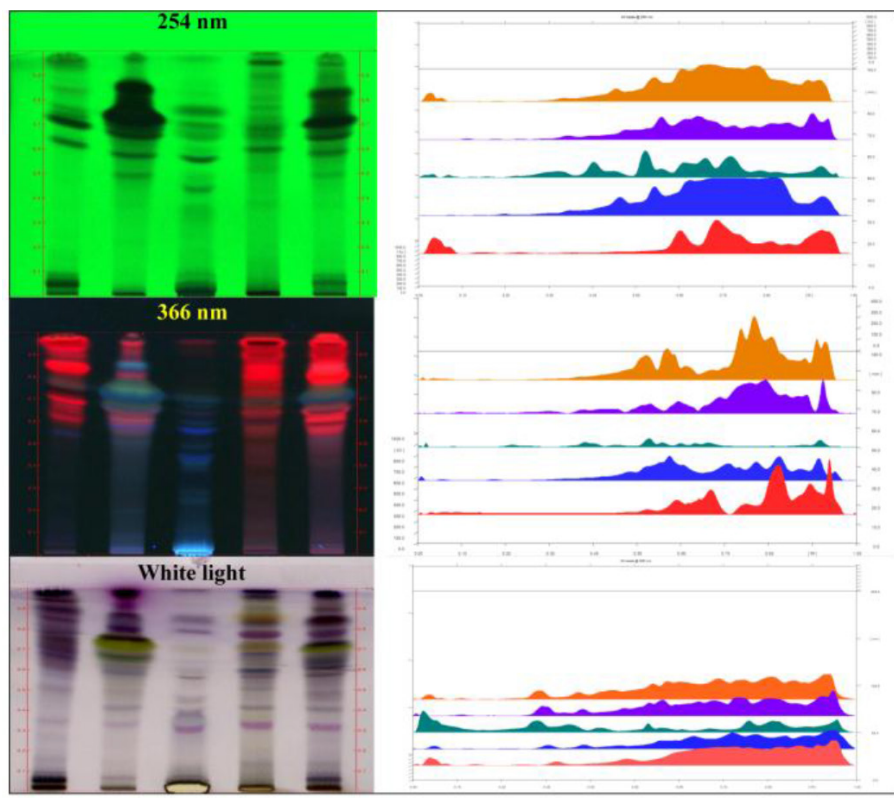

Figure 4: TLC and 3D chromatograms of ethanol extract of NKC with ingredients Track 1-5: V. negundo, P. nigrum, A. sativum, P. betel and NKC.

The DPPH radical scavenging activity of NKC extracts was detected and compared with standard ascorbic acid. The percentage of inhibition at various concentrations (Table 3 ) of NKC (aqueous-NKCAE and methanol-NKCME) as well as standard ascorbic acid $(25-500 \mu \mathrm{g} / \mathrm{ml})$ were calculated and plotted in graph (Figure 5). The test drug shows higher inhibition of about $71.17 \%$ for NKCAE, 75.63 for NKCME and the standard ascorbic acid exhibits $77.66 \%$ of inhibition at $500 \mu \mathrm{g} / \mathrm{ml}$ sample concentration. In lower concentration $25 \mu \mathrm{g} / \mathrm{ml}$, the test drug shows inhibition 23.28\% for NKCAE, 27.97\% for NKCME and the standard ascorbic acid exhibits $38.98 \%$ of inhibition the absorbance was measured at $517 \mathrm{~nm}$ using UV Spectrophotometer.

The superoxide radical scavenging of the extract of NKC were detected and compared with ascorbic acid standard (Table 3 ). The percentage of inhibition at various concentrations $(25-500 \mu \mathrm{g} / \mathrm{ml})$ of drug as well as standard ascorbic acid $(25-500 \mu \mathrm{g} / \mathrm{ml})$ were calculated and plotted in graph (Figure 5). The test drug shows higher inhibition of about $63.59 \%$ for NKCAE, $68.43 \%$ for NKCME and the standard ascorbic acid exhibits $72.49 \%$ of inhibition at $500 \mu \mathrm{g} / \mathrm{ml}$ sample concentration. In lower concentration $25 \mu \mathrm{g} / \mathrm{ml}$, the test drug shows inhibition $9.92 \%$ for NKCAE, 24.24\% for NKCME and the standard ascorbic acid exhibits $18.26 \%$ of inhibition. The absorbance was measured at $560 \mathrm{~nm}$ using UV spectrophotometer.

\section{DISCUSSION}

The main reason behind the need for the evaluation of crude drug microscopically is to rule out any adulteration and substitutions if any. Microscopic examination of the powdered compounded formulation revealed the presence of elongated epidermal cells with anamocytic stomata and spiral vessels which is in accordance to the previous studies carried out in $A$. sativum; ${ }^{10-13}$ thin epidermal cells with cyclocytic stomata, glandular trichomes with pearl glands and the prismatic crystals obtained during powder microscopy can be attributed to $P$. betel leaves and affirms the former studies; ${ }^{14-17}$ broad and rectangular sclereids seen in abundance arranged laterally, bearer cells, starch grains granules both agglomerated and scattered and the vascular elements can serve as a diagnostic tool for identifying $P$. nigrum fruits and were consistent 
Thatipelli, et al.: Pharmacognostic and Antioxidant Studies on Noccik Kudinir Chooranam

Table 3: Free radical scavenging activity by NKC.

\begin{tabular}{|c|c|c|c|c|c|c|}
\hline \multirow[t]{2}{*}{ Concentration $(\mu \mathrm{g} / \mathrm{ml})$} & \multicolumn{3}{|c|}{ DPPH free radical Inhibition (\%) } & \multicolumn{3}{|c|}{ Superoxide anion radical inhibition (\%) } \\
\hline & Ascorbic Acid & CCAE & CCME & Ascorbic Acid & CCAE & CCME \\
\hline 25 & 38.98 & 23.28 & 27.97 & 18.26 & 9.92 & 24.24 \\
\hline 75 & 47.97 & 51.48 & 53.05 & 33.03 & 29.88 & 41.26 \\
\hline 100 & 56.95 & 61.02 & 68.36 & 47.46 & 33.26 & 51.18 \\
\hline 400 & 70.63 & 67.27 & 75.23 & 70.91 & 62.12 & 63.92 \\
\hline 500 & 77.66 & 71.17 & 75.63 & 72.49 & 63.59 & 68.43 \\
\hline
\end{tabular}

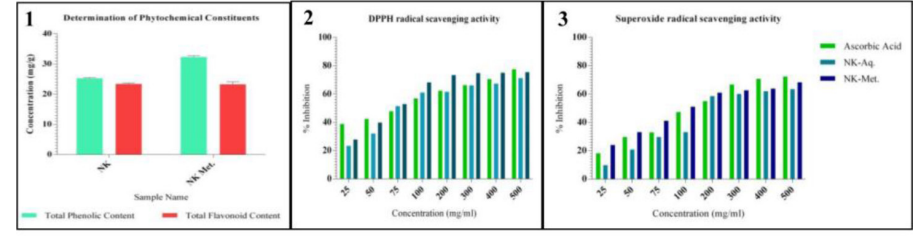

Figure 5: Antioxidant activity of NKC. 1 - Total phenol/flavonoid; 2 - DPPH radical scavenging; 3 - Super oxide anion radical scavenging.

with previous studies. ${ }^{18-20} \mathrm{~V}$. negundo leaf powder contains an immense amount of heteromorphic trichomes varying from simple to multicellular, short, conical, thick walled, warty and glandular trichomes and a large number of rosette crystals which were obtained in the current study and co relates to the previous studies. ${ }^{21,22}$ The morphology of the various tissues and cells of the plants are species specific and diagnostic as a result the powder microscopic characterization can be effectively used as a diagnostic tool to identify the various components of compound formulations.

The physico-chemical parameters are the basic study carried out for herbal drugs. The loss drying gives the total content of moisture and volatile oil. All the ingredients of the study drug contain volatile to quantifiable amount and the moisture of fresh garlic also led to this high value of the loss on drying. However, the volatile oil present in the ingredient will prevent the drug from deterioration. ${ }^{23}$ The total ash of the study drug, $6.17 \%$ represents the inorganic salts which is a primary metabolite required for physiological functions of human body. Low intake of these nutrients may lead to loss of calcium and thereby leads to even death. ${ }^{24,25}$ The water soluble ash of the study drug indicates that the $2.61 \%$ of ash are soluble in water and remaining is acid soluble ashes. The alcohol soluble and the water soluble extractives, $27.60 \%$ and $41.40 \%$ respectively are an indicative of the solubility of the secondary metabolite constituents in the high polar organic and inorganic solvents. The $\mathrm{pH} 6.49$ shows that the drug is acidic despite the presence of alkaloid and would have longer shelf life. The kudinir (dosage form) also remains in acidic $\mathrm{pH}$ of 6.57. The specific gravity of the decoction is 1.03 . The $n$-hexane soluble extract was calculated as $4 \%$ in which most of the non polar compounds would be extracted and the chloroform soluble extractive was evaluated as $3.50 \%$ which represents the medium polar compounds the methanol extractive indicates the presence of high polar compounds to the extent of $9 \%$.

The non-polar compounds were separated and shown in the TLC of hexane extract, medium polar compounds in the TLC of chloroform extract, polar compounds in the TLC of ethyl acetate extract, high polar compounds in the TLC of ethanol, hydroalcohol and aqueous extracts.

The amount of total phenolic content was found to be $25.23 \pm 0.3 \mathrm{mg} / \mathrm{g}$ for NKCAE and $32.32 \pm 0.406 \mathrm{mg} / \mathrm{g}$ for NKCME of gallic acid equivalents. The flavonoid content was found to be $23.04 \pm 0.353 \mathrm{mg} / \mathrm{g}$ for NKCAE and $23.26 \pm 0.829 \mathrm{mg} / \mathrm{g}$ for NKCME of quercetin equivalents. The inhibitory activity of DPPH radical by $\mathrm{NKCAE}\left(\mathrm{IC}_{50}=74.3 \pm 0.467 \mu \mathrm{g} / \mathrm{ml}\right)$ and NKCME $\left(\mathrm{IC}_{50}=72.70 \pm 0.174 \mu \mathrm{g} / \mathrm{ml}\right)$ was better when compared to the scavenging activity of ascorbic acid $\left(\mathrm{IC}_{50}=78.2 \pm 0.272 \mu \mathrm{g} / \mathrm{ml}\right)$. The superoxide radical scavenging activity of ascorbic acid $\left(\mathrm{IC}_{50}=123.79 \pm 0.279 \mu \mathrm{g} / \mathrm{ml}\right)$ was better when compared to NKCAE $\left(\mathrm{IC}_{50}=179.24 \pm 0.345 \mu \mathrm{g} / \mathrm{ml}\right)$ and NKCME $\left(\mathrm{IC}_{50}=196.45 \pm 0.768 \mu \mathrm{g} / \mathrm{ml}\right)$.

The phytochemical literature of the ingredients shows that the drug has variety of phytoconstitutes. ${ }^{26-35}$ The ingredients were reported with many pharmacological activities. ${ }^{36-51}$ Previous epidemiological studies report that these antioxidant compounds also possess anti inflammatory, antiatherosclerotic, antitumor, antimutagenic, anticarcinogenic, antibacterial and antiviral activities to greater or lesser extent. ${ }^{52-54}$ Hence the study drug would have anti-inflammatory, analgesic, anti-tumour, anti cancer, anti-arthritic and anti-rheumatic activities.

\section{CONCLUSION}

The identified microscopic characters would help to check the NKC drug for proper inclusion of individual ingredients. The physicochemical results, TLC/HPTLC of different extracts of NKC and Kudinir would be useful for the quality control investigation of the drug. As reported by earlier researchers, as the drug is exhibiting the DPPH free radical scavenging and superoxide anion radical scavenging activities, the drug leaves broad scope for the pharmacologist for further studies. For facilities and support.

\section{ACKNOWLEDGEMENT}

Authors are thankful to The Director General, CCRS and The Assistant Director I/c, SCRI.

\section{CONFLICT OF INTEREST}

The authors declare no conflict of interest.

\section{ABBREVIATIONS}

$\mathrm{NaOH}$ : Sodium hydroxide; DPPH: $\alpha$, $\alpha$ - diphenyl- $\beta$-picrylhydrazyl.

\section{REFERENCES}

1. Anonymous. The Siddha Formulary of India. Part I, $1^{\text {st }}$ Edition. Department of Health, Ministry of Health and Family Welfare, Government of India, New Delhi. 
1979;161.

2. Dina A, Nassima C, Meriem B, Karima A, Hakima L, Hania B. Antioxidant capacity and phenol content of selected Algerian medicinal plants. Food Chem. 2009;112(2):303-9

3. Bagchi D, Bagchi M, Stohs SJ, Das DK, Ray SD, Kuszynski CA, et al. Free radicals and grape seed proanthocyanidin extract: Importance in human health and disease prevention. Toxicology. 2000;148(2-3):187-97.

4. Evans WC. Pharmacognosy. W.B. Saunders Company Ltd, fifteenth Edition. 2002;541-5.

5. Lohar DR. Protocol for testing of Ayurveda, Siddha and Unani medicine. New Delhi, Pharmacopoeial Laboratory for Indian Medicine, Department of AYUSH, Ministry of Health and Family Welfare, Government of India. 2008.

6. Anand D, Shanmugasundaram D, Sasikumar CS, Cherian SM, Cherian KM. Development of an antidiabetic formulation (ADJ6) and its inhibitory activity against $\alpha$-amylase and $\alpha$-glucosidase. J Tradit Complement Med. 2016;6(3):204-8.

7. Cameron GR, Milton RF, Allan JW. Measurement of flavonoids in plant sample. Lancet. 1943;179.

8. Brand-Williams W, Cuvelier M, Berset C. Use of a free radical method to evaluate antioxidant activity. LWT - Food Sci Technol. 1995;28(1):25-30.

9. Kumar RS, Rajkapoor B, Perumal P. Antioxidant activities of Indigofera cassioides Rottl. Ex. DC. using various in vitro assay models. Asian Pac J Trop Biomed. 2012;2(4):256-61.

10. Quality standards of Indian Medicinal Plants: ICMR, New Delhi. 2008;3:38-47.

11. Kadam PV, Yadav KN, Karjikar FA, Patel FA, Patidar MK, Patil MJ. Pharmacognostic, phytochemical and physicochemical studies of Allium sativum Linn. Bulb (Liliaceae). Int J Pharm Sci Res. 2013:4(9);3524-31.

12. Pendbhaje NS, Narang AP, Pathan SM, Raotole SA, Pattewar SV. Ethnopharmacology, pharmacognosy and phytochemical profile of Allium sativum: A Review. Pharmacologyonline 2011;2:845-53.

13. The Ayurvedic Pharmacopoeia of India. Government of India, Ministry of Health and Family Welfare, Department of Indian System of Medicine and Homeopathy, New Delhi, First Edition, Part-I. 1999;3:108-9.

14. Wallis TE. Text book of Pharmacgnosy, Fifth edition, CBS Publishers and Distributors, New Delhi. 2005;108-11.

15. Qaulity standards of Indian Medicinal Plants. ICMR, New Delhi. 2008;7:198-207.

16. Deepak P, Suri KA, Pradhan DK, Biswasroy P. Golden Heart of the Nature: Piper betle L. J Pharmacogn Phytochem. 2013;1(6):147-67.

17. Malaysian Herbal Monograph, Herbal Monograph Committee. Kuala Lumpur: Forest Research Institute Malaysia. 2009;2.

18. Trivedi MN, Khemani A, Vachhani UD, Shah CP, Santani DD. Pharmacognostic, phytochemical analysis and antimicrobial activity of two Piper species. Int J Comp Pharm. 2011;7(05):1-4.

19. Rai N, Yadav S, Verma AK, Tiwari L, Sharma RK. Quality specifications on Piper nigrum L.-A spice and herbal drug of Indian commerce. Int J Adv Food Sci Technol. 2012;1(1):1-11

20. Quality Standards of Indian Medicinal Plants; ICMR, New Delhi. 2008;8:255-63.

21. Quality Standards of Indian Medicinal Plants; ICMR, New Delhi. 2008;3:357-9.

22. The Ayurvedic Pharmacopoeia of India. Government of India, Ministry of Health and Family Welfare, Department of Indian System of Medicine and Homeopathy, New Delhi, First Edition, Part-I. 1999:4:76-7.

23. Burt S. Essential oils: Their antibacterial properties and potential application in foods-a review. Int J Food Microbiol. 2004;94(3):223-53.

24. Smith $A H$, Schults RV. Effects of diet poor in inorganic salts on certain organs and blood of young rats. Am J Physiol. 1930;94(1):107-17

25. Brooke RO, Smith AH. Inorganic salts in nutrition: VI. The mineral metabolism of rats receiving a diet low in inorganic constituents. J Biol Chem. 1933;100:105-24.

26. Singh SS, Agarwal SK, Verma S, Siddiqui MS, Kumar S. Chemistry of garlic(Allium sativum) with special reference to alliin and allicin - A review. J Med Aromat Plant Sci. 1998;20:93-100.

27. Zeigler SJ, Sticher O. HPLC of S-alk(en)yl-L-cysteine derivatives in garlic including quantitative determination of $(+)$-S-allyl-L-cysteine sulphoxide (Alliin). Planta Med. 1989;55(4):372-8.

28. Dutta PK, Chowdhury US, Chakravarty AK, Achari B, Pakrashi SC. Studies on
Indian medicinal plants-part LXXV. Nishindaside, a novel iridoid glycoside from Vitex negundo Linn. Tetrahedron. 1983;39(9):3067-72.

29. Mallavarapu GR, Ramesh S, Kaul PN, Bhattacharya AK, Rajeshwar RBR Composition of the essential oil of the leaves of Vitex negundo. Planta Med. 1994;60(6):583-4.

30. Rawat AKS, Tripathi RD, Khan AJ, Balasubrhmanyam VR. Essential oil components as markers for identification of Piper betle L. cultivars. Biochem Syst Ecol. 1989;17(1):35-8

31. Jirovetz L, Puschmann C, Buchbauer G, Fleischhacker W, Shafi PM, Arif MM. Analysis of the essential oil of Piper betle Linn. Leaves from South-India using GC/FID, GC/MS and olfactometry. Sci Pharm. 1999;67C:PS77.

32. Deshpande SM, Upadhyay RR, Singh RP. Chemical study of Piper betel leaves. Curr Sci. 1970;39:372

33. Nakatani N, Inatani R, Miyakado M. Constituents of Piper nigrum L. Lloydia. 1978;41:653.

34. Miyakado M, Nakayama I, Yoshioka H, Nakatani N. The Piperaceae amides I: Structure of pipercide, a new insecticidal amide from Piper nigrum L. Agric Biol Chem. 1979;43(7):1609-11.

35. Nakatani N, Inatani R. Isobutyl amides from pepper (Piper nigrum L.). Agric Biol Chem. 1981;45(6):1473-6

36. Tsai Y, Cole LL, Davis LE, Lockwood SJ, Simmons V, Wild GC. Antiviral properties of garlic: In vitro effects on influenza B Herpes simplex and Coxsackie viruses. Planta Med. 1985;51(5):460-1.

37. Anesini C, Perez C. Screening of plants used in Argentine folk medicine for antimicrobial activity. J Ethnopharmacol. 1993;39(2):119-28.

38. Kumar BP, Chary MAS, Reddy SM. Screening of plant extracts for antifungal properties. New Bot. 1979;6:41-3.

39. Arivazhagan S, Balasenthil S Nagini S. Garlic and neem leaf extracts enhance hepatic glutathione and glutathione dependent enzymes during $\mathrm{N}$-methyl$\mathrm{N}$-nitro-N-nitroso guanidine (MNNG) induced gastric carcinogenesis in rats. Phytother Res. 2000;6:7-11.

40. Prasad DN, Bhattacharya SK, Das PK. A study of anti-inflammatory activity of some indigenous drugs in albino rats. Indian J Med Res. 1966;54(6):582-8.

41. Shah SA, Vohora SB. Boron enhances anti-arthritic effects of garlic oil. Fitoterapia. 1990;61(2):121-5.

42. Telang RS, Chatterjee S, Varshneya C. Studies on analgesic and anti-inflammatory activities of Vitex negundo Linn. Indian J Pharmacol. 1999;31(5):363-6.

43. Tamhankar CP, Saraf MN. Anti-arthritic activity of Vitex negundo Linn. Indian J Pharm Sci. 1994;37:143-6.

44. Rusia K Srivastava SK. Antimicrobial activity of some Indian medicinal plants. Indian J Pharm Sci. 1998;60:57-8.

45. Murakami A, Ali AM, Mat-Salleh K, Koshimizu K, Ohigashi H. Screening for the in vitro anti tumor promoting activities of edible plants from Malaysia. Biosci Biotech Biochem. 2000;64(1):9-16.

46. Panda S, Kar A. Betel leaf extract can be both antiperoxidative and peroxidative in nature. Curr Sci. 1998;74(4):284-5.

47. Dasgupta N, De B. Antioxidant activity of Piper betle L. leaf extract in vitro. Food Chem. 2004;88(2):219-24

48. Rajendhran J, Mani MA, Navaneethakannan K. Antibacterial activity of some selected medicinal plants. Geobios. 1998;25:280-2.

49. Banger GP, Rao RE, Varma KC. Antimicrobial activity of leaves and oil of Piper betle Linn. Indian J Pharm. 1966;28:327-8.

50. Santhanam G, Nagarajan S. Wound healing activity of Curcuma aromatic and Piper betle. Fitoterapia. 1990;61(5):458-9.

51. Kaleem M, Sheema SH, Bano B. Protective effects of piper nigrum and Vinca rosea in alloxan induced diabetic rats. Indian J Physiol Pharmacol. 2005;49(1):65-71.

52. Mitscher LA, Telikepalli Natural antimutagenic agents.Mutat Res. 1996;350(1):142-3.

53. Owen RW, Giacosa A, Hull WE, Haubner R, Spiegelhalder B, Bartsch H. The antioxidant/anticancer potential of phenolic compounds isolated from olive oil. Eur J Cancer. 2000;36(10):1235-47.

54. Sala A, Recio MD, Giner RM, Manez S, Tournier H, Schinella G, et al. Antiinflammatory and antioxidant properties of Helichrysum italicum. J Pharm Pharmacol. 2002;54(3):365-71.

Article History: Submission Date : 30-05-2019; Revised Date : 23-08-2019; Acceptance Date : 18-09-2019.

Cite this article: Sujith T, Shakila R, Mandal AK, Divya KG, Mahesh F, Sunilkumar KN, Ganesan R. Powder Microscopic, Physicochemical, HPTLC and Antioxidant Studies on Noccik Kudinir Chooranam - A Polyherbal Siddha Formulation. J Young Pharm. 2019;11(4):371-6. 